\title{
SPECTOMYCINS, NEW ANTIBACTERIAL COMPOUNDS PRODUCED BY Streptomyces spectabilis: ISOLATION, STRUCTURES, AND BIOSYNTHESIS
}

\author{
ANDrew L. Staley and KenNeth L. RineharT* \\ Roger Adams Laboratory, University of Illinois, \\ 600 So. Mathews Ave., Urbana, IL 61801, U.S.A.
}

(Received for publication May 30, 1994)

\begin{abstract}
Three new tetrahydroanthracene antibiotics have been isolated from modified culture broths of Streptomyces spectabilis. The new compounds, spectomycins $\mathrm{Al}, \mathrm{A} 2$ and $\mathrm{B} 1$, exist as monomeric $\left(\mathrm{C}_{20} \mathrm{H}_{20} \mathrm{O}_{7}, \mathrm{Al} ; \mathrm{C}_{19} \mathrm{H}_{18} \mathrm{O}_{7}, \mathrm{~A} 2\right)$ and as symmetrical dimeric $\left(\mathrm{C}_{38} \mathrm{H}_{34} \mathrm{O}_{14} ; \mathrm{B} 1\right)$ forms. Only spectomycin $\mathrm{B} 1$ has moderate activity against Gram-positive microorganisms. We report here the structure elucidation and biosynthetic origin of these compounds.
\end{abstract}

During our ongoing studies of the biosynthesis of the streptovaricins, ${ }^{1)}$ it became necessary to develop a medium that was suitable for the production of mutants of $S$. spectabilis. We found an appropriate, soluble synthetic growth medium that supported high production and growth profiles of the organism, but bioautography of the fermentation extracts indicated that the bioactivity vs B. subtilis was not due to the production of any known streptovaricins. Instead, the activity was associated with two series of new, unidentified metabolites whose structures have been determined by spectral and chemical methods. We report here the structure elucidation of the first series of compounds, which we have trivially named spectomycins A1, A2, and B2 $(\mathbf{1 a} \sim \mathbf{c}) .{ }^{2)}$ These compounds, which proved to be members of the aureolic acid class of antibiotics, are most closely related to julimycins ${ }^{3,4}$ and exist as a mixture of monomeric and dimeric species. The second series of bioactive metabolites (deoxymonamycins) ${ }^{2)}$ will be reported separately.

\section{Results}

\section{Detection and Isolation}

A number of synthetic and semisynthetic media were screened for the production of bioactive components by dipped disk assay vs $B$. subtilis. The filtered culture broth and an ethyl acetate extract of the broth (2.5-fold concentration of the organic extract versus the culture broth) were assayed separately. Antimicrobial activity was detected in most of the culture broths, but organic-extractable activity was

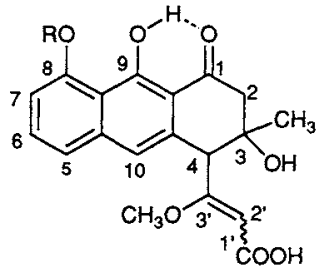

$1 a$ Spectomycin $\mathrm{A} 1\left(\mathrm{R}=\mathrm{CH}_{3}\right)$

1b Spectomycin $\mathrm{A} 2(\mathrm{R}=\mathrm{H})$<smiles></smiles>

1c Spectomycin B1 
observed only in Medium I ( $1.0 \%$ glucose, $1.0 \%\left(\mathrm{NH}_{4}\right)_{2} \mathrm{SO}_{4}, 0.35 \% \mathrm{NaCl}, 0.25 \% \mathrm{~K}_{2} \mathrm{HPO}_{4}, 0.15 \%$ $\mathrm{KH}_{2} \mathrm{PO}_{4}, 0.01 \% \mathrm{CaCO}_{3}$, and $0.01 \% \mathrm{Na}_{2} \mathrm{~S} \cdot 9 \mathrm{H}_{2} \mathrm{O}$ in tap water) and Medium II (Medium I supplemented with $0.5 \%$ yeast extract (DIFCO)). Production of the organic-extractable activity commenced at 48 hours after inoculation and persisted until the culture was worked up at 140 hours after inoculation. Although good production of streptovaricins was noted by TLC of the extract from Medium II, none could be detected in the extract from Medium I. Bioautography of the extract from Medium I (silica gel, chloroform-methanol, $9: 1$ ) vs B. subtilis indicated a large zone of activity from Rf 0.4 to 0.6 , but this activity could not be attributed to the production of any known streptovaricin components.

A large-scale fermentation was conducted in 200 liters of Medium I. The whole broth was extracted at the final $\mathrm{pH} 3.9$ with ethyl acetate ( $3 \sim 4$ liters per 12-liter batch of beer). The combined extracts were concentrated to $500 \mathrm{ml}$ and partitioned with $5 \%$ aqueous sodium bicarbonate. The aqueous layers, after acidification and re-extraction, provided a mixture of crude carboxylic acids that was separated by chromatography on silica gel and Sephadex LH-20. Three main components were collected: 1a $(9.1 \mathrm{mg})$, $1 \mathbf{b}(120 \mathrm{mg})$, and $1 \mathrm{c}(324 \mathrm{mg})$. The dimeric compound $1 \mathrm{c}$ showed an MIC of $2 \mu \mathrm{g} / \mathrm{ml}$ against $B$. subtilis by dipped disk assay, but was inactive against $E$. coli, S. cerevisiae, and $P$. atrovenatum. The compound demonstrated complete viral inhibition against Herpes simplex virus I (HSV-I) at $100 \mu \mathrm{g} / \mathrm{ml}$. In its antiviral activity it resembled the more active crisamicin A1. ${ }^{5)}$ The monomeric compounds $\mathbf{1 a}$ and $\mathbf{1 b}$ showed no activity in the assays.

\section{Structure Elucidation}

The structures of the compounds were determined in part by spectral analysis, particularly long- and short-range ${ }^{1} \mathrm{H}^{-1}{ }^{13} \mathrm{C}$ heteronuclear correlations (attached proton test and HETCOR), and were confirmed by chemical conversions. An HREI mass spectrum for $\mathbf{1 b}$ provided a molecular ion at $\mathrm{m} / \mathrm{z} 358.1060$ $\left(\mathrm{C}_{19} \mathrm{H}_{18} \mathrm{O}_{7}, \Delta 0.3 \mathrm{mmu}\right)$, implying eleven degrees of unsaturation. An HRFAB mass spectrum of $1 \mathrm{c}$ provided a molecular ion $(\mathrm{M}+\mathrm{H})$ at $m / z 715.2039\left(\mathrm{C}_{38} \mathrm{H}_{35} \mathrm{O}_{14}, \Delta 1.2 \mathrm{mmu}\right)$, which is consistent with a symmetrical dimerization of $1 \mathbf{b}$ (i.e., $2 \times 358-\mathrm{H}_{2}$ ). The $360-\mathrm{MHz}$

${ }^{1} \mathrm{H}$ NMR spectral data for each of the spectomycins are presented in Table 1 , and the $90-\mathrm{MHz}^{13} \mathrm{CNMR}$ data are presented in Table 2 . The ${ }^{13} \mathrm{C}$ NMR spectral data are consistent with the mass spectral data, in that nineteen carbon resonances are observed for both $\mathbf{1 b}$ and $\mathbf{1 c}$, implying (again) dimerization of the former to provide the latter. Compound 1a was isolated as a minor component from the broth, and provided a molecular ion (HREI-MS) at $\mathrm{m} / \mathrm{z}$ $372.1261\left(\mathrm{C}_{20} \mathrm{H}_{20} \mathrm{O}_{7}, \Delta 2.6 \mathrm{mmu}\right)$, and twenty signals in the ${ }^{13} \mathrm{C}$ NMR spectrum, including an $\mathrm{O}-\mathrm{CH}_{3}$ carbon at $56.1 \mathrm{ppm}$, implying that it is an $O$ methylated derivative of $\mathbf{1 b}$.

In the ${ }^{1} \mathrm{H}$ NMR spectrum of $\mathbf{1 b}$ a series of three ortho-coupled aromatic protons was observed at $7.52(\mathrm{t}), 7.15(\mathrm{~d})$, and $6.83(\mathrm{~d}) \mathrm{ppm}$, and an aromatic

Table 1. ${ }^{1} \mathrm{H}$ NMR spectral data for the spectomycins.

\begin{tabular}{|c|c|c|c|}
\hline \multirow[b]{2}{*}{ Proton } & \multicolumn{3}{|c|}{ Spectomycin } \\
\hline & $\begin{array}{c}\mathbf{1 a}^{\mathbf{a}} \\
\delta \mathrm{ppm} \\
\text { mult, }{ }^{\mathrm{c}} J(\mathrm{~Hz})\end{array}$ & $\begin{array}{c}\mathbf{1 b}^{\mathbf{a}} \\
\delta \text { ppm } \\
\text { mult, }{ }^{\mathrm{c}} J(\mathrm{~Hz})\end{array}$ & $\begin{array}{c}1 \mathbf{c}^{\mathrm{b}} \\
\delta \mathrm{ppm} \\
\text { mult, }{ }^{\mathrm{c}} J(\mathrm{~Hz})\end{array}$ \\
\hline $2 a$ & $3.05, \mathrm{~d}, 17.4$ & $3.05, \mathrm{~d}, 17.6$ & $3.08, \mathrm{~d}, 17.5$ \\
\hline $2 b$ & $2.82, \mathrm{~d}, 17.4$ & $2.94, \mathrm{~d}, 17.6$ & $2.88, \mathrm{~d}, 17.5$ \\
\hline 4 & $5.48, \mathrm{~s}$ & $5.50, \mathrm{~s}$ & $5.78, \mathrm{~s}$ \\
\hline 5 & $7.20, \mathrm{~d}, 8.0$ & $7.15, \mathrm{~d}, 8.0$ & $7.36, \mathrm{~d}, 8.3$ \\
\hline 6 & $7.50, t, 8.0$ & $7.52, t, 8.0$ & $7.68, \mathrm{~d}, 8.3$ \\
\hline 7 & $6.84, \mathrm{~d}, 8.0$ & $6.83, \mathrm{~d}, 8.0$ & \\
\hline 10 & $6.88, \mathrm{~s}$ & $6.89, \mathrm{~s}$ & $7.12, \mathrm{~s}$ \\
\hline $3-\mathrm{CH}_{3}$ & $1.42, \mathrm{~s}$ & $1.43, \mathrm{~s}$ & $1.42, \mathrm{~s}$ \\
\hline $8-\mathrm{OH}$ & & $9.75, \mathrm{~s}$ & $9.82, \mathrm{~s}$ \\
\hline $8-\mathrm{OCH}_{3}$ & $4.02, \mathrm{~s}$ & & \\
\hline $9-\mathrm{OH}$ & $16.08, \mathrm{~s}$ & $16.10, \mathrm{~s}$ & $15.98, \mathrm{~s}$ \\
\hline $2^{\prime}$ & $5.44, \mathrm{~s}$ & $5.48, \mathrm{~s}$ & $5.56, \mathrm{~s}$ \\
\hline $3^{\prime}-\mathrm{OCH}_{3}$ & $3.69, \mathrm{~s}$ & $3.72, \mathrm{~s}$ & $3.78, \mathrm{~s}$ \\
\hline
\end{tabular}

${ }^{\mathrm{a}}$ In $\mathrm{CDCl}_{3} \cdot{ }^{\mathrm{b}}$ In $\mathrm{CD}_{3} \mathrm{COCD}_{3} \cdot{ }^{\mathrm{c}}$ Multiplicity: s, singlet; $\mathrm{d}$, doublet; t, triplet; q, quartet. 
Table 2. ${ }^{13} \mathrm{C}$ NMR spectral data for the spectomycins.

\begin{tabular}{|c|c|c|c|c|c|}
\hline Carbon & $\mathrm{m}^{\mathrm{a}}$ & $1 a^{b}$ & $\mathbf{1 b}^{\mathrm{b}}$ & $1 \mathrm{c}^{\mathrm{c}}$ & 2b \\
\hline 1 & $\mathrm{~s}$ & 202.6 & 202.4 & 205.2 & 195.4 \\
\hline 2 & $t$ & 49.7 & 49.4 & 50.4 & 51.7 \\
\hline 3 & s & 71.8 & 72.1 & 72.4 & 71.7 \\
\hline 4 & d & 50.8 & 50.3 & 50.9 & 51.6 \\
\hline $4 a$ & $s$ & 135.1 & 134.0 & 136.9 & 136.4 \\
\hline 5 & $\mathrm{~d}$ & 120.0 & 118.4 & 118.7 & 118.4 \\
\hline 6 & $\mathrm{~d}$ & 131.2 & 132.7 & 136.5 & 130.8 \\
\hline 7 & $d$ & 106.2 & 111.5 & $121.0(\mathrm{~s})$ & 111.4 \\
\hline 8 & s & 159.8 & 158.0 & 155.7 & 156.2 \\
\hline $8 a$ & $\mathrm{~s}$ & 115.5 & 112.9 & 113.5 & 119.7 \\
\hline 9 & $\mathrm{~s}$ & 165.7 & 165.4 & 166.3 & 159.6 \\
\hline $9 \mathrm{a}$ & $\mathrm{s}$ & 111.2 & 109.1 & 110.9 & 116.7 \\
\hline 10 & $\mathrm{~d}$ & 117.4 & 118.0 & 118.6 & 123.8 \\
\hline $10 \mathrm{a}$ & s & 139.8 & 138.9 & 139.7 & 138.0 \\
\hline $3-\mathrm{CH}_{3}$ & $q$ & 29.1 & 28.9 & 29.0 & 29.3 \\
\hline $8-\mathrm{OCH}_{3}$ & $\mathrm{q}$ & 56.1 & & & \\
\hline $9-\mathrm{OCH}_{3}$ & $q$ & & & & 64.4 \\
\hline $1^{\prime}$ & $s$ & 172.9 & 172.9 & 169.3 & 169.1 \\
\hline $2^{\prime}$ & $d$ & 94.7 & 95.1 & 95.8 & 95.2 \\
\hline $3^{\prime}$ & $\mathrm{s}$ & 174.8 & 174.4 & 173.6 & 172.6 \\
\hline $\mathrm{I}^{\prime}-\mathrm{OCH}_{3}$ & $q$ & & & & 51.5 \\
\hline $3^{\prime}-\mathrm{OCH}_{3}$ & $\mathrm{q}$ & 56.4 & 56.4 & 56.5 & 56.1 \\
\hline
\end{tabular}

${ }^{a}$ Multiplicity: s, singlet; d, doublet; t, triplet; q, quartet. ${ }^{b}$ In $\mathrm{CDCl}_{3} .{ }^{\mathrm{c}}$ In $\mathrm{CD}_{3} \mathrm{COCD}_{3}$.

singlet was observed at $6.89 \mathrm{ppm}$. Two singlets at 5.50 and $5.48 \mathrm{ppm}$ were thought at first to correspond to two olefinic resonances, but a heteronuclear correlation experiment indicated that the proton at $5.50 \mathrm{ppm}$ was actually an aliphatic methine proton with a very odd, downfield chemical shift (vide infra). Also observed were resonances for $O$-methyl (3.72 ppm) and $C$-methyl $(1.43 \mathrm{ppm})$ singlets, a pair of AB doublets (3.05 and $2.82 \mathrm{ppm})$, and two phenolic hydroxyls $(9.75$ and $16.10 \mathrm{ppm})$. The chemical shift at $16.10 \mathrm{ppm}$ suggested a strongly chelated hydroxyl proton from the enol form of a 1,3-diketone or a peri-hydroxy naphthoquinone. The infrared spectrum $\left(1682 \mathrm{~cm}^{-1}\right)$ and acidic behavior of the compound suggested the presence of a conjugated carboxylic acid, although the proton for this functional group was not observed. In all, the ${ }^{1} \mathrm{H}$ NMR spectrum could account for a total of sixteen of the eighteen protons, and another two protons $(-\mathrm{OH}$ and $-\mathrm{COOH})$ may have been buried in the baseline. The lack of additional coupling information did not permit assignment of further structural units.

The ${ }^{13} \mathrm{C}$ NMR spectrum of $\mathbf{1 b}$ showed resonances for a ketone (202.4 ppm), an acid (172.9 ppm), and the $\alpha$-carbon of an enol methyl ether (174.4 ppm). An olefinic carbon far upfield at $95.1 \mathrm{ppm}$ was assigned to the $\beta$-carbon of the enol ether. In addition, ten resonances for aromatic-type carbons, two of which were phenol-bearing carbons ( 165.4 and $158.0 \mathrm{ppm}$ ) and four of which were substituted by hydrogen (132.7, $118.4,118.0$ and $111.5 \mathrm{ppm}$ ), implied a naphthalene ring system with two oxygen and two carbon substituents. An aliphatic methine carbon $(50.3 \mathrm{ppm})$, a methylene carbon $(49.4 \mathrm{ppm})$, an $O$-methyl (56.4 ppm), a $C$-methyl $(28.9 \mathrm{ppm})$, and an oxygen-substituted quaternary carbon $(72.1 \mathrm{ppm})$ accounted for the remaining resonances, for a total of nineteen carbons. The naphthalene ring, ketone and carboxylate carbonyls, and the enol ether accounted for ten of the eleven degrees of unsaturation, suggesting the presence of another ring.

Unequivocal assignments for the resonances could be obtained from short-range and long-range 


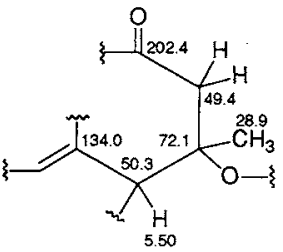

Fragment A

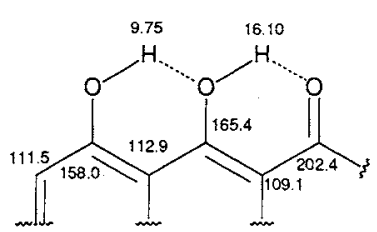

Fragment B

heteronuclear correlations. Assignment of the shortrange correlations for the $O$-methyl, $C$-methyl, methylene, methine, and four aromatic resonances was straightforward. The proton singlets at 5.50 and $5.48 \mathrm{ppm}$ were clearly attached to rather distinct carbons (an aliphatic methine carbon at $50.3 \mathrm{ppm}$ and an olefinic carbon at $95.1 \mathrm{ppm}$, respectively). The long-range HETCOR spectrum provided correlation between the proton $O$-methyl singlet at $3.72 \mathrm{ppm}$ and the carbon resonance at $174.4 \mathrm{ppm}$ ( $\alpha$-carbon of the enol ether). The proton $C$-methyl absorption at $1.43 \mathrm{ppm}$ was correlated with carbon resonances for the methine ( $50.3 \mathrm{ppm})$, methylene

(49.4 ppm), and quaternary (72.1 ppm) carbons. Both of the methylene protons (3.05 and $2.82 \mathrm{ppm})$ and the aliphatic methine proton $(5.50 \mathrm{ppm})$ were also correlated with the quaternary carbon. Hence, an aliphatic carbon framework consisting of a quaternary carbon attached to a methyl, a methine, a methylene, and an oxygen substituent could be constructed. Because the methine proton at $5.50 \mathrm{ppm}$ was correlated with the aromatic carbon at $134.0 \mathrm{ppm}$, and the methylene protons with the ketone carbon at $202.4 \mathrm{ppm}$, Fragment A can be drawn.

Further evidence includes correlations between the two phenolic hydrogen at $16.1 \mathrm{ppm}$ and the aromatic resonances at 109.1, 112.9, and $165.4 \mathrm{ppm}$, and the other phenolic hydrogen, at $9.75 \mathrm{ppm}$, with the carbon resonances at $111.5,112.9$, and $158.0 \mathrm{ppm}$. Since the phenolic hydrogen at $16.1 \mathrm{ppm}$ must be hydrogen-bonded to the ketone, Fragment B is implied. All of the relevant long-range correlations are summarized in Scheme 1. From a few remaining correlations and proton coupling systems the entire tetrahydroanthracene ring system can be constructed, with the 3-carbon sidechain assigned as the substituent at $\mathrm{C}-4$ by default. The methoxyl (correlated with the disubstituted olefinic carbon at $174.4 \mathrm{ppm}$ ) and the olefinic proton, on the olefinic carbon at $95.1 \mathrm{ppm}$ and not coupled to H-4, must be on opposite ends of the double bond. The carboxyl group must then be attached to the $\beta$-position of the enol ether group, as shown, and this is supported by the chemical shift of the olefinic $\beta$-proton at $5.48 \mathrm{ppm}$. The final proposed structure for the monomeric compound is shown as $\mathbf{1 b}$. The stereochemistry of the ring substituents and that of the olefinic double bond have not yet been rigorously determined.

The structures for $\mathbf{1 a}$ and $\mathbf{1 c}$ follow from a comparison of their spectral features with those of $\mathbf{1 b}$. Compound 1a contains one extra $O$-methyl group relative to $\mathbf{l b}$ as evidenced by EI-MS (molecular ion at $m / z$ 372), by the extra $O$-methyl resonance at $4.02 \mathrm{ppm}$ in the ${ }^{1} \mathrm{H}$ NMR spectrum, and by the $O$-methyl 


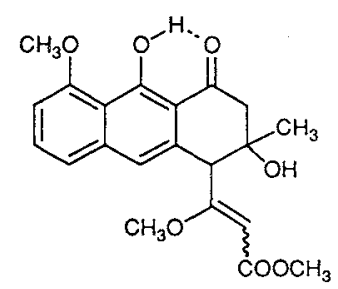

2

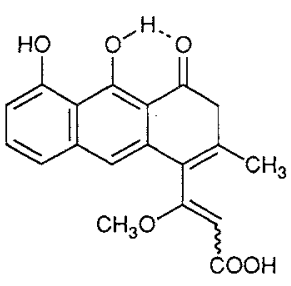

3

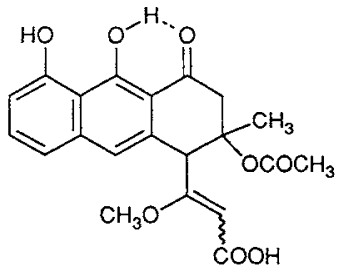

4

signal at $56.1 \mathrm{ppm}$ in the ${ }^{13} \mathrm{C}$ NMR spectrum. The methyl ether is located at C-8 because the strongly chelated enolic hydrogen of a 1,3-diketone ( $\mathrm{H}-9)$ is still observed at $16.1 \mathrm{ppm}$ in the ${ }^{1} \mathrm{H}$ NMR spectrum.

The structure of $\mathbf{1} \mathbf{c}$ is assigned as a symmetrical dimer $\mathbf{1 b}$. A FAB mass spectrum of $1 \mathbf{c}$ indicated an $\mathbf{M}+\mathbf{H}$ ion at $m / z 715$ (i.e., $\mathbf{M}=714=(2 \times 358, \mathbf{1 b})-2 \mathrm{H})$. All of the resonances for the two compounds are the same, with the exception of one fewer aromatic proton in the proton spectrum of 1c: the resonance for $\mathrm{H}-7$ in $\mathbf{1 b}$ (at 6.83 , furthest upfield of the four) is missing for $\mathbf{1 c}$, and slight downfield shifts for H-5 and $\mathrm{H}-6$ (both now doublets) are observed. In addition, a downfield shift to $121.0 \mathrm{ppm}$ for the resonance for $\mathrm{C}-7$ is observed in the carbon spectrum of $1 \mathrm{c}$.

\section{Chemical Conversions}

Treatment of $\mathbf{1 b}$ with ethereal diazomethane leads to a mixture of three products, the major one (2) being derived from the addition of two methyl groups (EI-MS, $m / z$ 386). By proton and carbon NMR, the new methyl groups can be assigned as a methyl ester and a methyl ether. That the methyl ether is located at $\mathrm{C}-9$ is indicated by the lack of a strongly hydrogen-bonded phenol resonance at $16.1 \mathrm{ppm}$ in the ${ }^{1} \mathrm{H}$ NMR spectrum of the compound, as well as by the large change in the chemical shift of the C-1 carbonyl resonance (to $195.4 \mathrm{ppm}$ ). The position of this methyl ether is, therefore, quite distinct from that of the methyl ether in the natural product 1a. The other two products of the reaction were not well characterized.

Treatment of $\mathbf{1 b}$ with methanol and catalytic sulfuric acid resulted in the formation of a single compound (3) that proved to be a dehydration product (EI-MS, $m / z$ 340). Because the resonance for the $\mathrm{H}-4$ proton disappears and the resonance for the C-3 methyl group shifts downfield to $1.62 \mathrm{ppm}$, the dehydration has occurred across the $\mathrm{C}-3, \mathrm{C}-4$ bond. Tautomerization of the ketone to the enol (providing an anthracene skeleton) does not occur.

Acetylation of $\mathbf{1 b}$ with acetic anhydride and triethylamine, followed by aqueous extractive workup, provided a monoacetate (4). That the acetyl group was introduced on the C-3 hydroxyl is evidenced by the retention of both phenol resonances at 16.1 and $9.8 \mathrm{ppm}$ in the proton NMR spectrum and by a slight downfield shift of the C-3 methyl group to $1.46 \mathrm{ppm}$. Upon attempted purification of the compound by silica gel chromatography, the acetate was converted to the same compound obtained from the methanolysis reaction (3).

Attempted cleavage of the $O$-methyl ether of $1 \mathrm{~b}$ with acetic acid and $48 \%$ aqueous hydrobromic acid provided an unstable, acidic compound which showed by FAB-MS a highest-mass fragment ion at $m / z$ $282\left(\mathrm{M}-\mathrm{CO}_{2}\right)$. Attempted purification by silica gel chromatography led to the quantitative conversion of the original product into a nonpolar compound which showed a molecular ion (FAB-MS) at $m / z 283$ $(\mathrm{M}+\mathrm{H})$. This sequence of reactions is consistent with an acid-catalyzed dehydration and cleavage of the methyl enol ether to the $\beta$-ketoacid $\mathbf{5 a}$, which then decarboxylates to provide the methyl ketone $\mathbf{5} \mathbf{b}$. 
Finally, a reduction of 1a with sodium borohydride in methanol, followed by a mildly acidic workup, provided the anthracene derivate $\mathbf{6 b}$. The product presumably arises from reduction of the ketone to the dihydroxy compound $\mathbf{6 a}$, followed by a double dehydration to the anthracene $\mathbf{6 b}$.

\section{Biosynthetic Studies}

S. spectabilis was grown as described above in 5 liters of Medium I in a jar fermentor. Sodium $\left[1,2-{ }^{13} \mathrm{C}_{2}\right]$ acetate $\left(700 \mathrm{mg}, 90 \%{ }^{13} \mathrm{C}\right.$ ) was dissolved in $20 \mathrm{ml}$ of water, sterilized by membrane filtration, and fed to the culture in two equal portions at 31 and 58 hours after inoculation. At 72 hours, the fermentation was worked up as described above to provide $53 \mathrm{mg}$ of $1 \mathrm{~b}$ and $47 \mathrm{mg}$ of $1 \mathrm{c}$ (along with<smiles>CC1=C(C(=O)CC(=O)O)c2cc3cccc(O)c3c(O)c2C(=O)C1</smiles>
$5 \mathbf{a}$<smiles>CC(=O)C1=C(C)CC(=O)c2c1cc1cccc(O)c1c2O</smiles>
$\mathbf{5 b}$<smiles>COC(=CC(=O)O)C1c2cc3cccc(OC)c3c(O)c2[C@@H](O)CC1(C)O</smiles>
6a<smiles>CO/C(=C\C(=O)O)c1c(C)ccc2c(O)c3c(OC)cccc3cc12</smiles>

6b another $100 \mathrm{mg}$ of partially purified 1c). The ${ }^{13} \mathrm{C}$ NMR spectra of both compounds showed the ${ }^{13} \mathrm{C}$ ${ }^{13} \mathrm{C}$ coupling patterns expected for intact incorporation of acetate units into a nonaketide biogenetic

Scheme 2. Incorporation of $\left[1,2-{ }^{13} \mathrm{C}_{2}\right]$ acetate into $\mathbf{1 b}$ and $1 \mathrm{c}$.<smiles></smiles>

Table 3. Coupling constants for incorporation of $\left[1,2-{ }^{13} \mathrm{C}_{2}\right]$ acetate and enrichment factors for incorporation of $\left[1-{ }^{13} \mathrm{C}\right]$ acetate into $\mathbf{1 b}$ and $1 \mathbf{c}^{\mathbf{a}}$.

\begin{tabular}{|c|c|c|c|c|c|}
\hline \multirow{2}{*}{ Carbon } & \multicolumn{3}{|c|}{$1 b^{b}$} & \multicolumn{2}{|c|}{$1 c^{c}$} \\
\hline & $\delta \mathrm{ppm}$ & ${ }^{1} J_{\mathrm{C}-\mathrm{C}}$ & Enrichment $^{d}$ & $\delta \mathrm{ppm}$ & ${ }^{1} J_{\mathrm{C}-\mathrm{C}}$ \\
\hline 3-Me & 28.9 & 40.2 & 1.0 & 29.0 & 38.6 \\
\hline 3 & 72.4 & 39.8 & 2.9 & 72.4 & 40.0 \\
\hline 2 & 51.0 & 40.5 & 1.1 & 51.1 & 40.6 \\
\hline 1 & 205.2 & 40.4 & 2.1 & 205.1 & 40.9 \\
\hline $9 \mathrm{a}$ & 110.8 & 68.8 & 1.6 & 111.1 & 65.5 \\
\hline 9 & 165.8 & 63.8 & 3.6 & $(165.0)^{\mathrm{e}}$ & \\
\hline $8 a$ & 111.7 & 56.1 & 2.0 & 113.5 & 62.8 \\
\hline 8 & 158.7 & 62.2 & 3.3 & 155.5 & 62.1 \\
\hline 7 & 111.6 & 56.7 & 1.0 & 121.0 & 57.9 \\
\hline 6 & 133.3 & 56.2 & 2.2 & 136.4 & 57.8 \\
\hline 5 & 119.3 & 56.5 & 0.8 & 118.6 & 56.0 \\
\hline $10 \mathrm{a}$ & 140.2 & 56.6 & 4.9 & 139.7 & 55.9 \\
\hline 10 & 118.6 & 66.3 & 0.9 & 118.9 & 65.8 \\
\hline $4 a$ & 137.0 & 65.9 & 2.8 & 136.9 & 66.4 \\
\hline 4 & 50.2 & 48.7 & 0.9 & 50.5 & 48.6 \\
\hline $3^{\prime}$ & 173.5 & 48.8 & 3.3 & 173.6 & 48.7 \\
\hline $2^{\prime}$ & 95.9 & 78.6 & 0.8 & 95.9 & 78.6 \\
\hline $1^{\prime}$ & 169.3 & 78.5 & 3.6 & 169.5 & 78.6 \\
\hline $3^{\prime}-\mathrm{OMe}$ & 56.5 & & 1.0 & 56.5 & \\
\hline
\end{tabular}

${ }^{\mathrm{a}}$ In $\mathrm{CD}_{3} \mathrm{COCD}_{3} \cdot{ }^{\mathrm{b}} 16 \mathrm{~K}$ data size with zero filling to $32 \mathrm{~K}$ over $16393 \mathrm{~Hz}$ spectral width. ${ }^{\circ} 64 \mathrm{~K}$ data size over $16393 \mathrm{~Hz}$ spectral width. ${ }^{\mathrm{d}}$ Ratio of peak heights, normalized to the $3^{\prime}$ - $O$-methyl as 1.0. ${ }^{\mathrm{e}}$ Observed as a broad, pooriy resolved signal. 
precursor, as summarized in Table 3. A similar experiment was done with sodium $\left[1-{ }^{13} \mathrm{C}\right]$ acetate $(615 \mathrm{mg}$ in two equal portions at 48 and 60 hours after inoculation), providing $9.8 \mathrm{mg}$ of $\mathbf{1 b}$ and $2.1 \mathrm{mg}$ of $1 \mathrm{c}$. The enrichment factors observed in the ${ }^{13} \mathrm{C}$ NMR spectrum for $\mathbf{1 b}$ are also summarized in Table 3 . The incorporation pattern summarized in Scheme 2 provides additional evidence for the proposed structure, as the carbon skeleton can be traced from well-established carbon signal assignments by pairing signals with identical coupling constants. The only unlabeled carbon signal (the 3'-OMe carbon) should be derived from the $S$-methyl of methionine. The dimeric structure presumably arises from two monomeric species via oxidative phenolic coupling.

\section{Experimental}

General Methods

${ }^{1} \mathrm{H}$ and ${ }^{13} \mathrm{C} \mathrm{NMR}$ spectra were obtained on either a General Electric QE-300 at $300 \mathrm{MHz}$ or a Nicolet NT-360 spectrometer at $360 \mathrm{MHz}$. Heteronuclear correlation experiments were obtained on a General Electric GN-500 spectrometer at $500 \mathrm{MHz}$ with the software (CSCM and CSCMLR experiments) supplied by the manufacturer. IR spectra were obtained on an IBM IR-30S Fourier transform spectrophotometer, and UV spectra on a Perkin-Elmer Lambda 3 UV spectrophotometer. EI-MS was performed on a Finnigan-MAT CH5 instrument at $70 \mathrm{eV}$ and FAB-MS on either a VG Analytical ZAB-SE or a VG 70-SE $4 \mathrm{~F}$ four sector instrument with xenon fast atom gun using a dithiothreitol-dithioerythritol matrix ("Magic Bullet"). ${ }^{6)}$ Melting points were obtained on a Reichert hot stage melting point apparatus. Optical rotations were obtained on a JASCO DIP-360 digital recording optical rotation instrument in 100-mm cells. Sodium $\left[1,2-{ }^{13} \mathrm{C}_{2}\right]$ acetate was purchased from ICN Biomedicals, and sodium $\left[1-{ }^{13} \mathrm{C}\right]$ acetate from MSD Isotopes. Thin layer chromatography was on silica gel plates with indicator $(0.25 \mathrm{~mm}$, Kieselgel 60 F-254, Merck, Darmstadt). Silica gel for chromatography $(40 \sim 63 \mu \mathrm{m})$ was purchased from Merck, and Sephadex LH20 was obtained from Pharmacia.

\section{Culture Conditions}

S. spectabilis (UC 2294) was maintained in soil stocks and agar slants $(10.0 \mathrm{~g}$ of maltose, $5.0 \mathrm{~g}$ of DIFCO tryptone, $1.0 \mathrm{~g}$ of $\mathrm{K}_{2} \mathrm{HPO}_{4}, 1.0 \mathrm{~g}$ of $\mathrm{NaCl}$, a trace of $\mathrm{FeSO}_{4}$, and $15.0 \mathrm{~g}$ of agar per liter of distilled water). A seed culture in $100 \mathrm{ml}$ of Medium III (20.0 g of Sheffields NZ-Amine B, $10.0 \mathrm{~g}$ of glucose, $2.5 \mathrm{~g}$ of $\mathrm{K}_{2} \mathrm{HPO}_{4}, 1.5 \mathrm{~g}$ of $\mathrm{K}_{2} \mathrm{HPO}_{4}$, and $10.0 \mathrm{ml}$ of La Choy soy sauce per liter of distilled water) in a $500-\mathrm{ml}$ wide-mouthed Erlenmeyer flask was inoculated with a few grains of soil stock and incubated at $32^{\circ} \mathrm{C}$ and $250 \mathrm{rpm}$ in a New Brunswick G-25 rotary incubator for 48 hours. A $10.0 \mathrm{-ml}$ aliquot of the seed medium was then inoculated into 10 liters of synthetic Medium I in a 14-liter glass jar (New Brunswick Microferm), and incubated at $30^{\circ} \mathrm{C}$ with $250 \mathrm{rpm}$ agitation and an aeration rate of 5 liters/minute for 4 days. The entire culture broth was then inoculated into 200 liters of Medium I in a 250-liter New Brunswick fermentor at $30^{\circ} \mathrm{C}$, with $250 \mathrm{rpm}$ agitation rate and 100 liters/minute aeration rate, and incubated for 8 days.

\section{Isolation and Purification}

By the end of the fermentation the $\mathrm{pH}$ had dropped to 3.9. The whole beer was batch-extracted with ethyl acetate $(2 \times 3.0$ liters per 12-liter batch). The combined organic extracts were concentrated to $500 \mathrm{ml}$ by rotary evaporation at $40^{\circ} \mathrm{C}$, washed with water $(200 \mathrm{ml})$, and back-extracted with $5 \%$ sodium bicarbonate $(4 \times 100 \mathrm{ml})$. The combined bicarbonate layers were reacidified to $\mathrm{pH} 4.0$ with $6 \mathrm{~N}$ hydrochloric acid and extracted again with ethyl acetate $(3 \times 200 \mathrm{ml})$. The combined organic layers were washed with water $(50 \mathrm{ml})$ and brine $(2 \times 50 \mathrm{ml})$, then dried $\left(\mathrm{Na}_{2} \mathrm{SO}_{4}\right)$. After removal of the ethyl acetate, the crude, dark brown extract was dissolved in $20 \mathrm{ml}$ of chloroform and flash chromatographed on silica, from which the main yellow band was eluted with chloroform - methanol, 9:1. After evaporation of the solvent, the residue was dissolved in $35 \mathrm{ml}$ of chloroform, applied to a column of Sephadex LH-20 (300 ml), and eluted with a chloroform - methanol gradient. Three main bands eluted at $1,000 \mathrm{ml}$ of chloroform (fraction A), $1,500 \mathrm{ml}$ of chloroform (fraction B), and $500 \mathrm{ml}$ of $95: 5$ chloroform - methanol (fraction C). 
Fraction A was purified by reprecipitation from ethyl acetate - hexane to provide $9.1 \mathrm{mg}$ of a bright yellow powder (1a). Fraction B was purified by silica gel chromatography with a chloroform - methanol step gradient to yield $170 \mathrm{mg}$ of a dark yellow powder (1b). Fraction $\mathrm{C}$ was purified by reprecipitation from ethyl acetate - hexane to provide $324 \mathrm{mg}$ of a dark, orange-brown powder (1c).

Spectomycin A1 (1a): mp $118 \sim 122{ }^{\circ} \mathrm{C} ;{ }^{1} \mathrm{H}$ NMR (Table 1); ${ }^{13} \mathrm{C}$ NMR (Table 2); IR (Nujol) 1684, $1616,1576,1456,1398,1373,1267,1155,1097,843 \mathrm{~cm}^{-1}$; UV (MeOH) $\lambda_{\max }(\log \varepsilon) 402(3.95), 295(3.60)$, 284 (3.66), 258 (4.54), 215 (4.53); UV ( $(\mathrm{MeOH}-\mathrm{NaOH}) \lambda_{\max }(\log \varepsilon) 422(4.01), 335(3.51), 258(4.46), 215$ (4.45); EI-MS $m / z$ 372, 354, 322, 310, 294, 270, 254, 165, 152, 144. HREI-MS. Found: $m / z 372.1235$ (M). Calcd for $\mathrm{C}_{20} \mathrm{H}_{20} \mathrm{O}_{7}: m / z 372.1261$.

Spectomycin A2 (1b): $\mathrm{mp} 136 \sim 138^{\circ} \mathrm{C}$; $[\alpha]_{\mathrm{D}}^{25}-225^{\circ}\left(\mathrm{c} 0.25, \mathrm{CHCl}_{3}\right) ;{ }^{1} \mathrm{H}$ NMR (Table 1$) ;{ }^{13} \mathrm{C}$ NMR (Table 2); IR (Nujol) 3450, 1682, 1630, 1447, 1414, 1379, 1333, 1271, 1196, 1165, 1109, 1049, 991, 835, $808,796,771,736,702 \mathrm{~cm}^{-1}$; UV $(\mathrm{MeOH}) \lambda_{\max }(\log \varepsilon) 399(3.91), 260(4.54), 215(4.49) ; \mathrm{UV}(\mathrm{MeOH}-\mathrm{NaOH})$ $\lambda_{\max }(\log \varepsilon) 420$ (4.03), 260 (4.43), 215 (4.53); EI-MS $m / z$ 358, 340, 326, 308, 296, 280, 256, $240,165$. HREI-MS. Found: $m / z 358.1057$ (M). Calcd for $\mathrm{C}_{19} \mathrm{H}_{18} \mathrm{O}_{7}: m / z 358.1060$.

Spectomycin B1 (1c): mp $118 \sim 122^{\circ} \mathrm{C} ;{ }^{1} \mathrm{H}$ NMR (Table 1); ${ }^{13} \mathrm{C}$ NMR (Table 2); IR (Nujol) 3400, $1684,1618,1506,1406,1327,1242.1192,1155,1107,1051,833 \mathrm{~cm}^{-1}$; UV (MeOH) $\lambda_{\max }(\log \varepsilon) 430(4.14)$, 269 (4.43), 224 (4.37); FAB-MS $m / z 715(\mathrm{M}+\mathrm{H})$. HRFAB-MS. Found: $m / z 715.2039(\mathrm{M}+\mathrm{H})$. Calcd for $\mathrm{C}_{38} \mathrm{H}_{35} \mathrm{O}_{14}: m / z 717.2027$.

Methylation of $1 \mathbf{b}$. Excess ethereal diazomethane was added to $21.3 \mathrm{mg}$ of $1 \mathrm{~b}$ in $1.0 \mathrm{ml}$ of methanol at $0^{\circ} \mathrm{C}$ and the mixture was stirred at $25^{\circ} \mathrm{C}$ for 2 hours. The solvent was evaporated under a stream of nitrogen to yield $23.2 \mathrm{mg}$ of a yellow residue as a mixture of compounds. The major product $(10.4 \mathrm{mg})$ was isolated by silica gel chromatography $(99: 1$ chloroform-methanol), and was shown to be 9-O-methylspectomycin A2 methyl ester (2), mp 128 130 ${ }^{\circ} \mathrm{C} ;{ }^{1} \mathrm{H}$ NMR $\left(\mathrm{CDCl}_{3}\right) \delta 9.92(1 \mathrm{H}, \mathrm{s}, \mathrm{C}-8-\mathrm{OH})$, $7.45(1 \mathrm{H}, \mathrm{t}, J=7.8 \mathrm{~Hz}, \mathrm{H}-6), 7.31(1 \mathrm{H}, \mathrm{s}, \mathrm{H}-10), 7.22(1 \mathrm{H}, \mathrm{d}, J=7.9 \mathrm{~Hz}, \mathrm{H}-5), 6.89(1 \mathrm{H}, \mathrm{d}, J=7.7 \mathrm{~Hz}$, H-7), $5.52\left(1 \mathrm{H}, \mathrm{s}, \mathrm{H}-2^{\prime}\right), 4.06\left(3 \mathrm{H}, \mathrm{s}, 9-\mathrm{OCH}_{3}\right), 3.78\left(3 \mathrm{H}, \mathrm{s}, 3^{\prime}-\mathrm{OCH}_{3}\right), 3.64\left(3 \mathrm{H}, \mathrm{s}, 1^{\prime}-\mathrm{OCH}_{3}\right), 2.98(1 \mathrm{H}$, d, $J=17.4 \mathrm{~Hz}, \mathrm{H}-2 \mathrm{a}), 2.78(1 \mathrm{H}, \mathrm{d}, J=17.4 \mathrm{~Hz}, \mathrm{H}-2 \mathrm{~b}), 1.41\left(3 \mathrm{H}, \mathrm{s}, 3-\mathrm{CH}_{3}\right) ;{ }^{13} \mathrm{C}$ NMR (Table 2); IR (Nujol) $1686,1653,1628,1437,1346,1269,1145,1105,850 \mathrm{~cm}^{-1}$; UV $(\mathrm{MeOH}) \lambda_{\max }(\log \varepsilon) 380(3.2), 258(4.0)$, 220 (4.1); FAB-MS $m / z 387(\mathrm{M}+\mathrm{H}), 369\left((\mathrm{M}+\mathrm{H})-\mathrm{H}_{2} \mathrm{O}\right), 337\left((\mathrm{M}+\mathrm{H})-\mathrm{H}_{2} \mathrm{O}-\mathrm{CH}_{3} \mathrm{OH}\right)$. HRFAB-MS. Found: $m / z$ 387.1426. Calcd for $\mathrm{C}_{21} \mathrm{H}_{23} \mathrm{O}_{7}: m / z 387.1408$.

Methanolysis of $1 \mathrm{~b}$. A solution of $4.1 \mathrm{mg}$ of $1 \mathrm{~b}$ in $3.0 \mathrm{ml}$ of methanol and $0.2 \mathrm{ml}$ of concentrated sulfuric acid was stirred overnight at $25^{\circ} \mathrm{C}$. The mixture was cooled to $0^{\circ} \mathrm{C}$, and a light yellow solid precipitated from the solution. After filtration and washing with cold methanol, $2.4 \mathrm{mg}$ of a yellow powder, 3,4-didehydro-3-deoxyspectomycin $\mathrm{A} 2(3)$, was obtained, mp $144 \sim 146{ }^{\circ} \mathrm{C} ;{ }^{1} \mathrm{H}$ NMR $\left(\mathrm{CDCl}_{3}\right) \delta 15.9(1 \mathrm{H}$, brs, 9-OH), $9.67(1 \mathrm{H}, \mathrm{s}, 8-\mathrm{OH}), 7.54(1 \mathrm{H}, \mathrm{t}, J=7.8 \mathrm{~Hz}, \mathrm{H}-6), 7.19(1 \mathrm{H}, \mathrm{d}, J=7.8 \mathrm{~Hz}, \mathrm{H}-5), 7.17(1 \mathrm{H}, \mathrm{s}$, $\mathrm{H}-10), 6.93(1 \mathrm{H}, \mathrm{d}, J=7.8 \mathrm{~Hz}, \mathrm{H}-7), 5.28\left(1 \mathrm{H}, \mathrm{s}, \mathrm{H}-2^{\prime}\right), 3.86\left(3 \mathrm{H}, \mathrm{s}, 3^{\prime}-\mathrm{OCH}_{3}\right), 3.33(1 \mathrm{H}, \mathrm{d}, J=17.2 \mathrm{~Hz}$, H-2a), 2.93 (1H, d, $J=17.2 \mathrm{~Hz}, \mathrm{H}-2 \mathrm{~b}$ ), $1.62\left(3 \mathrm{H}, \mathrm{s}, 3-\mathrm{CH}_{3}\right.$ ); IR (Nujol) 1697, 1628, 1412, 1366, 1345, 1260, $1229,1188,1163,1107,1064,1010,856,822,629 \mathrm{~cm}^{-1}$; UV (MeOH) $\lambda_{\max }(\log \varepsilon) 407$ (3.77), $267(4.35)$, 220 (4.38); EI-MS $m / z$ (\% rel int) 340 (13.3), 322 (12.6), 308 (100.0), $148(53.4) ;$ FAB-MS $m / z 341(\mathrm{M}+\mathrm{H})$, $323\left((\mathrm{M}+\mathrm{H})-\mathrm{H}_{2} \mathrm{O}\right), 297\left((\mathrm{M}+\mathrm{H})-\mathrm{CO}_{2}\right), 241\left((\mathrm{M}+\mathrm{H})-\mathrm{C}_{4} \mathrm{H}_{4} \mathrm{O}_{3}\right)$. HRFAB-MS. Found: $m / z$ 341.1031. Calcd for $\mathrm{C}_{19} \mathrm{H}_{17} \mathrm{O}_{6}: m / z$ 341.1037.

Acetylation of $1 \mathbf{b}$. Triethylamine $(0.2 \mathrm{ml})$ was added to $6.1 \mathrm{mg}$ of $\mathbf{1 b}$ in $1.5 \mathrm{ml}$ of acetic anhydride and the mixture was stirred overnight at $25^{\circ} \mathrm{C}$. Excess reagent was quenched by the addition of methanol at $0^{\circ} \mathrm{C}$, and the mixture was poured into $20 \mathrm{ml}$ of water. The aqueous suspension was extracted with $10 \mathrm{ml}$ of ethyl acetate, and the organic layer was washed successively with $5 \mathrm{ml}$ each of $5 \%$ aqueous hydrochloric acid, water, and brine. After drying $\left(\mathrm{Na}_{2} \mathrm{SO}_{4}\right)$ and evaporation, the dark orange product was dissolved in $1 \mathrm{ml}$ of ethyl acetate and $3 \mathrm{ml}$ of hexane was added. A small amount of dark red precipitate was filtered off and discarded, and the filtrate was evaporated to give $4.8 \mathrm{mg}$ of a light yellow powder (4), $\mathrm{mp} 133 \sim 135^{\circ} \mathrm{C}$; ${ }^{1} \mathrm{H}$ NMR $\left(\mathrm{CDCl}_{3}\right) \delta 16.08(1 \mathrm{H}, \mathrm{s}, 9-\mathrm{OH}), 9.75(1 \mathrm{H}, \mathrm{s}, 8-\mathrm{OH}), 7.31(1 \mathrm{H}, \mathrm{t}, J=7.8 \mathrm{~Hz}, \mathrm{H}-6), 7.16(1 \mathrm{H}, \mathrm{d}$, $J=7.9 \mathrm{~Hz}, \mathrm{H}-5), 6.95(1 \mathrm{H}, \mathrm{s}, \mathrm{H}-10), 6.88(1 \mathrm{H}, \mathrm{d}, J=7.8 \mathrm{~Hz}, \mathrm{H}-7), 5.45\left(1 \mathrm{H}, \mathrm{s}, \mathrm{H}-2^{\prime}\right), 5.39(1 \mathrm{H}, \mathrm{s}, \mathrm{H}-4)$, $3.75\left(3 \mathrm{H}, \mathrm{s}, 3^{\prime}-\mathrm{OCH}_{3}\right), 3.08(1 \mathrm{H}, \mathrm{d}, J=17.7 \mathrm{~Hz}, \mathrm{H}-2 \mathrm{a}), 2.82(1 \mathrm{H}, \mathrm{d}, J=17.7 \mathrm{~Hz}, \mathrm{H}-2 \mathrm{~b}), 2.29(3 \mathrm{H}, \mathrm{s}$, $\mathrm{CH}_{3} \mathrm{COO}-, 1.46\left(3 \mathrm{H}, \mathrm{s}, 3-\mathrm{CH}_{3}\right)$; FAB-MS $m / z 401(\mathrm{M}+\mathrm{H})$. The compound was not further characterized due to its low purity at this point. Attempted purification of the compound by silica gel chromatography led to the elimination of acetic acid to provide a product identical with that obtained from the methanolysis 
(3).

Acid hydrolysis of $\mathbf{1 b}$. A $6.2-\mathrm{mg}$ portion of $\mathbf{1 b}$ was dissolved in a mixture of $2 \mathrm{ml}$ of acetic acid and $1 \mathrm{ml}$ of $48 \%$ aqueous hydrobromic acid and the solution was stirred at $25^{\circ} \mathrm{C}$ overnight. The mixture was then poured into $20 \mathrm{ml}$ of water and extracted with $10 \mathrm{ml}$ of ethyl acetate. The organic layer was washed with $5 \mathrm{ml}$ each of water and brine, then dried $\left(\mathrm{Na}_{2} \mathrm{SO}_{4}\right)$. Evaporation of the solvent provided $5.6 \mathrm{mg}$ of a yellow-orange powder which proved to be highly unstable. The product had $\operatorname{Rf} 0.18$ on silica (chloroform - methanol, 9:1), and FAB-MS provided a highest-mass fragment ion at $m / z 282\left(\mathrm{M}-\mathrm{CO}_{2}\right)$. Upon standing in solution or chromatography on silica, the compound converted rapidly and quantitatively to a less polar product ( Rf 0.9, chloroform-methanol, 9:1), whose FAB mass spectrum indicated a molecular ion $(\mathrm{M}+\mathrm{H})$ at $m / z 283$. The above conversion is consistent with a decarboxylation of the $\beta$-keto acid 5a to the methyl ketone $\mathbf{5 b}, \mathrm{mp} 132 \sim 138^{\circ} \mathrm{C} ;{ }^{1} \mathrm{H} \mathrm{NMR}\left(\mathrm{CDCl}_{3}\right) \delta 7.49(1 \mathrm{H}, \mathrm{t}, J=6.8 \mathrm{~Hz}, \mathrm{H}-6), 6.91$ $(1 \mathrm{H}, \mathrm{d}, J=6.8 \mathrm{~Hz}, \mathrm{H}-5), 6.88(1 \mathrm{H}, \mathrm{d}, J=6.8 \mathrm{~Hz}, \mathrm{H}-7), 6.80(1 \mathrm{H}, \mathrm{s}, \mathrm{H}-10), 4.21(2 \mathrm{H}, \mathrm{s}, \mathrm{H}-2), 2.54(3 \mathrm{H}, \mathrm{s}$, 3- $\mathrm{CH}_{3}$ ), $2.33\left(3 \mathrm{H}, \mathrm{s}, \mathrm{CH}_{3} \mathrm{CO}-\right)$; IR (Nujol) $1695,1633,1610,1570,1458,1360,1280,1226,1180,914,854$, $769,748 \mathrm{~cm}^{-1} ;$ EI-MS $m / z$ (\% rel int) $282(62.8), 267$ (55.3), 240 (41.7). The compound was not characterized further.

Hydride reduction of 1a. A solution of $55 \mathrm{mg}$ of sodium borohydride in $3 \mathrm{ml}$ of methanol was added to a solution of $19.2 \mathrm{mg}$ of $1 \mathrm{a}$ in $1.5 \mathrm{ml}$ of methanol at $0^{\circ} \mathrm{C}$. After 1 hour at $0^{\circ} \mathrm{C}$, another $10 \mathrm{mg}$ of solid sodium borohydride was added, and the mixture was stirred for 1 hour at $25^{\circ} \mathrm{C}$. The mixture was acidified with $5 \mathrm{ml}$ of $5 \%$ aq hydrochloric acid then poured into $20 \mathrm{ml}$ of water. The aqueous solution was extracted with $10 \mathrm{ml}$ of ethyl acetate, and the organic layer was washed with $5 \mathrm{ml}$ each of water and brine. After drying and evaporation, $16.1 \mathrm{mg}$ of a yellow powder, 3-(9-hydroxy-8-methoxy-3-methylanthracen-4-yl)-3methoxypropanoic acid (6b), was obtained, $\mathrm{mp} 136 \sim 138^{\circ} \mathrm{C} ;{ }^{1} \mathrm{H}$ NMR $\left(\mathrm{CDCl}_{3}\right) \delta 10.13(1 \mathrm{H}, \mathrm{s}, \mathrm{H}-9), 8.34$ $(1 \mathrm{H}, \mathrm{d}, J=8.9 \mathrm{~Hz}, \mathrm{H}-1), 7.52(1 \mathrm{H}, \mathrm{s}, \mathrm{H}-10), 7.38(1 \mathrm{H}, \mathrm{d}, J=8.5 \mathrm{~Hz}, \mathrm{H}-5), 7.18(1 \mathrm{H}, \mathrm{d}, J=8.9 \mathrm{~Hz}, \mathrm{H}-2)$, $7.14(1 \mathrm{H}, \mathrm{dd}, J=8.5,7.5 \mathrm{~Hz}, \mathrm{H}-6), 6.51(1 \mathrm{H}, \mathrm{d}, J=7.5 \mathrm{~Hz}, \mathrm{H}-7), 5.61\left(1 \mathrm{H}, \mathrm{s}, \mathrm{H}-2^{\prime}\right), 4.01\left(3 \mathrm{H}, \mathrm{s}, 9-\mathrm{OCH}_{3}\right)$, $3.85\left(3 \mathrm{H}, \mathrm{s}, 3^{\prime}-\mathrm{OCH}_{3}\right), 2.32\left(3 \mathrm{H}, \mathrm{s}, 3-\mathrm{CH}_{3}\right) ;{ }^{13} \mathrm{C} \mathrm{NMR}\left(\mathrm{CDCl}_{3}\right) \delta 171.5(\mathrm{~s}), 170.4(\mathrm{~s}), 156.4(\mathrm{~s}), 151.1(\mathrm{~s})$, 134.2 (s, 2 C), 130.6 (s), 129.7 (s), 126.4 (d), 124.6 (d), 123.7 (s), 122.3 (d), 118.7 (s), 112.1 (d), 109.8 (s), 101.0 (d), 95.6 (d), 56.4 (q), 55.9 (q), 19.7 (q); IR (Nujol) 1708, 1667, 1624, 1593, 1469, 1269, 1078, 833, $787,711 \mathrm{~cm}^{-1}$; UV (MeOH) $\lambda_{\max }(\log \varepsilon) 320(3.0), 256(3.9), 238(3.9), 202(4.0)$; EI-MS $m / z(\%$ rel int) 338 (3.09), 307 (7.8), 293 (8.3), 279 (7.8), 265 (6.8); FAB-MS $m / z 339(\mathrm{M}+\mathrm{H}), 239\left((\mathrm{M}+\mathrm{H})-\mathrm{C}_{4} \mathrm{H}_{4} \mathrm{O}_{3}\right)$. HRFAB-MS. Found: $m / z 339.1224$ Calcd for $\mathrm{C}_{20} \mathrm{H}_{19} \mathrm{O}_{5}: m / z 339.1216$.

\section{Acknowledgments}

This work was supported in part by a grant from the National Institute of Allergy and Infectious Diseases (AI01278 to K.L.R.) and by an NIH National Research Service Award (GM-07283-14 to A.L.S.). We thank Alma DieTz (The Upjohn Company, Kalamazoo, MI) for supplying the strain of Streptomyces spectabilis (UC-2294) and Dr. G. R. WiLson for the antiviral assays.

\section{References}

1) Staley, A. L. \& K. L. Rinehart: Biosynthesis of the streptovaricins: 3-Amino-5-hydroxybenzoic acid as a precursor to the meta- $\mathrm{C}_{7} \mathrm{~N}$ unit. J. Antibiotics 44: $218 \sim 224,1991$

2) Staley, A. L.: Isolation, structure, synthesis and biosynthesis of selected bioactive microbial metabolites. Ph.D. Thesis, University of Illinois, Urbana, IL, 1990

3) Tsum, N. \& K. Nagashima: Studies on julimycins-II. The stereochemistry of julimycin B-II. Tetrahedron 24: $4233 \sim 4247,1968$

4) Tsujl, N. \& K. Nagashima: Studies on julimycins-VIII. The structures of julichromes $Q_{1-7}, Q_{8-8}, Q_{3-8}, Q_{3-3}$ and $Q_{1-9}$. Tetrahedron 27: $1557 \sim 1563,1971$

5) Ling, D.; L. S. Shield \& K. L. Rinehart, Jr.: Isolation and structure determination of crisamicin A, a new antibiotic from Micromonospora purpureochromogenes subsp. halotolerans. J. Antibiotics 39: 345 353, 1986

6) Witten, I. L.; M. H. Schaffer, M. O'shea, J. C. Cook, M. E. Hemling \& K. L. Rinehart: Structures of two cockroach neuropeptides assigned by fast atom bombardment mass spectrometry. Biochem. Biophys. Res. Commun. 124: 350 358, 1984 